\title{
Variations in Mycoplasma Morphology Induced by Long-chain Fatty Acids
}

\author{
By S. RAZIN,* B. J. COSENZA AND M. E. TOURTELLOTTE \\ Department of Bacteriology and Department of Animal Diseases, \\ University of Connecticut, Storrs, U.S.A.
}

(Received 12 August 1965)

\begin{abstract}
SUMMARY
Addition of unsaturated long-chain fatty acids to tryptose broth improved growth of Mycoplasma laidlawii and induced the formation of very long and highly branched filaments by this organism. Most filaments were composed of small coccoid bodies. The saturated long-chain fatty acids, in a similar concentration, did not produce this effect; palmitic and stearic acids inhibited growth. Similar, but less striking results were obtained with $M$. gallisepticum and Mycoplasma sp. strain 14. The possibility that the morphological variations reflect changes in the lipid composition of the cell membrane is discussed.
\end{abstract}

\section{INTRODUCTION}

Several mycoplasma species including Mycoplasma mycoides var. mycoides, $M$. gallisepticum and $M$. laidlawii require long-chain fatty acids for growth (Rodwell \& Abbot, 1961 ; Tourtellotte, Jensen, Gander \& Morowitz, 1963; Razin \& Rottem, 1963). Evidence for the incorporation and use of the fatty acids of the growth medium for the biosynthesis of mycoplasma lipids is accumulating (Smith \& Boughton, 1960; Tourtellotte et al. 1963; Argaman \& Razin, 1965). Since practically all mycoplasma lipids are part of the cell membrane (Razin, Argaman \& Avigan, 1963 ) it is evident that the long-chain fatty acids are important constituents of this structure. Growth of $\boldsymbol{M}$. mycoides var. mycoides in a medium deficient in essential long-chain fatty acids was accompanied by profound morphological changes in the cells, reflecting apparently defective biosynthesis of the limiting cell membrane (Rodwell \& Abbot, 1961).

The dependence of biosynthesis of membrane lipids on an external supply of longchain fatty acids prompted us to investigate the possibility of changing the fatty acid composition of the membrane by varying the fatty acid composition of the growth medium. The method chosen to approach this problem consisted of adding increasing amounts of one long-chain fatty acid at a time to the growth medium and observe its effects on cell morphology, osmotic fragility and fatty acid composition of membrane lipids. This report describes the morphological changes occurring in mycoplasma cells grown in the presence of various long-chain fatty acids.

* Present address: Department of Clinical Microbiology, The Hebrew University, Hadassah Medical School, Jerusalem, Israel. 


\section{METHODS}

Organisms. Mycoplasma laidlawii strain в (PG9) was obtained from Dr D. G. ff. Edward (Wellcome Research Laboratories, Beckenham, Kent). M. gallisepticum strain A 5969 was taken from the culture collection of the Department of Animal Diseases, University of Connecticut. Mycoplasma sp. strain 14 (goat strain) was obtained from Dr H. E. Adler (School of Veterinary Medicine, University of California, Davis, U.S.A.).

Growth conditions. The basal growth medium was tryptose broth consisting of (g./l.): Bacto-tryptose, 20; sodium chloride, 5; tris (2-amino-2-hydroxymethylpropane-1,3-diol), 5; glucose, 7 . The $\mathrm{pH}$ value of the medium was $8 \cdot 2-8 \cdot 4$ without adjustment. The medium was supplemented with $4 \mathrm{~g}$. lipid-extracted bovine albumin, fraction V (Calbiochem, Los Angeles, U.S.A.)/l. The albumin was extracted with acetone as described by Razin \& Rottem (1963). The saprophytic Mycoplasma laidlawii could grow well in this medium after an adaptation period of 10-20 daily transfers in the medium. The parasitic $M$. gallisepticum and the goat strain could not grow in this medium unless supplemented with Bacto-PPLO serum fraction in a final concentration of $1 \%(\mathrm{v} / \mathrm{v})$. Experiments to replace the need for PPLO serum fraction with mixtures of cholesterol and long-chain fatty acids failed to yield satisfactory growth of the two parasitic strains.

Long-chain fatty acids were added to the growth medium in ethanolic solution. The concentration of ethanol in the medium never exceeded $0.5 \%(v / v)$. The presence of lipid-extracted albumin in the medium enabled growth of Mycoplasma with rather high concentrations of fatty acids. Growth was usually done in $100 \mathrm{ml}$. quantities of medium dispensed in $200 \mathrm{ml}$. screw-capped bottles. Each bottle received $5 \mathrm{ml}$. of a $24 \mathrm{hr}$ culture in the medium with no fatty acids added. The bottles were incubated statically at $37^{\circ}$ for $24 \mathrm{hr}$ or longer and samples were taken for microscopic examinations.

Assessment of growth. The organisms were harvested by centrifugation at $9000 \mathrm{~g}$ for $15 \mathrm{~min}$. and washed twice in $\beta$-buffer (Pollack, Razin, Pollack \& Cleverdon, 1965) consisting of: sodium chloride, $0.15 \mathrm{M}$; tris, $0.05 \mathrm{M}$; 2-mercaptoethanol, $0.01 \mathrm{M}$ in de-ionized water, adjusted to $\mathrm{pH} \mathbf{7} \cdot 4$ with $\mathrm{HCl}$. The washed organisms were resuspended in $10 \mathrm{ml}$. buffer and the amount of cell protein determined in a sample of this suspension according to Lowry, Rosebrough, Farr \& Randall (1951).

Chemicals. Lauric acid (A grade, gas chromatography $>99 \cdot 5 \%$ pure), palmitic acid (A grade, gas chromatography homogeneous), stearic acid (A grade, gas chromatography homogeneous) and oleic acid (A grade, $>99 \%$ pure) were the products of Calbiochem (Los Angeles, California, U.S.A.). Myristic acid (99.8\% pure), linoleic acid $(90+\%$ pure), linolenic acid $(99+\%$ pure) and arachidonic acid (90 + \% pure) were purchased from Mann Research Laboratories Inc. (New York 6, N.Y., U.S.A.).

Microscopy and photomicrography. Drops taken from the liquid cultures of the tested Mycoplasma were put on glass slides, covered with coverslips and examined with a Wild M20 microscope. The Wild Fluotar phase objective HI50/1.00 and a $\times 10$ or $\times 20$ eyepiece were routinely used. The illumination source was a Bausch and Lomb low-voltage lamp. Photographs were taken with a Leitz Wetzlar camera using Kodak Contrast Process panchromatic film. The total microscopic magnifica- 
tion was 625. Prints were made on Kodabromide (F-3) paper to a final magnification of 1250,2700 or 3850.

\section{RESULTS}

Mycoplasma laidlawii. Growth of $M$. laidlawii in the tryptose medium was characterized by a steep decline phase involving lysis of the organisms within $48-72 \mathrm{hr}$ incubation at $37^{\circ}$. Addition of increasing concentrations of oleic acid to this medium improved growth and lengthened the decline phase. The concentration of oleic acid giving optimal growth was about $50 \mu \mathrm{g} . / \mathrm{ml}$; higher concentrations decreased growth. Growth promotion was also shown with the other unsaturated fatty acids linoleic acid and linolenic acid, and to a lesser extent with arachidonic acid (Table 1). While lauric acid promoted growth, the other saturated long-chain fatty acids inhibited growth; the growth-inhibitory effect increased with the increase in the chain length (Table 1).

Table 1. Effect of long-chain fatty acids on growth of Mycoplasma laidlawii strain $B$

\begin{tabular}{|c|c|c|c|}
\hline \multicolumn{4}{|c|}{$\begin{array}{l}\text { Organisms were grown in } 100 \mathrm{ml} \text {. quantities of tryptose broth containing } 0 \cdot 4 \%(\mathrm{v} / \mathrm{v}) \\
\text { lipid-extracted bovine albumin, fraction } \mathrm{V} \text {, and } 50 \mu \mathrm{g} . / \mathrm{ml} \text {. of one of the fatty acids. } \\
\text { The organisms were harvested after } 24 \mathrm{hr} \text { incubation at } 37^{\circ} \text {, washed and resuspended in } \\
\beta \text {-buffer. Total cell protein in the suspension was determined according to Lowry et al. } \\
\text { (1951). }\end{array}$} \\
\hline $\begin{array}{c}\text { Fatty acid } \\
\text { added to medium }\end{array}$ & $\begin{array}{l}\text { Cell protein } \\
\text { (mg.) }\end{array}$ & $\begin{array}{c}\text { Fatty acid } \\
\text { added to medium }\end{array}$ & $\begin{array}{l}\text { Cell protein } \\
\text { (mg.) }\end{array}$ \\
\hline Oleic & $11 \cdot 0$ & Myristic & $5 \cdot 1$ \\
\hline Linoleic & $12 \cdot 9$ & Palmitic & $3 \cdot 7$ \\
\hline Linolenic & $12 \cdot 9$ & Stearic & $\mathbf{2 \cdot 0}$ \\
\hline Arachidonic & $8 \cdot 4$ & No fatty acid added & $\mathbf{5} \cdot \mathbf{2}$ \\
\hline Lauric & $9 \cdot 8$ & & \\
\hline
\end{tabular}

The different effects of the long-chain fatty acids on the growth of Mycoplasma laidlawii were also expressed by profound morphological variations in the organisms. $\boldsymbol{M}$. laidlawii grown in the tryptose medium with no fatty acid added appeared as spherical bodies, either single, in pairs or arranged in short, frequently branching chains (Pl. 1, fig. 1). Addition of any one of the four unsaturated fatty acids caused the organisms to grow as long and branched filaments. Most filaments were composed of small spheres (Pl. 1, fig. 3). In many cases microcolonies, composed of entangled filaments, were formed in the liquid culture (Pl. 2, fig. 4). In small microcolonies the filaments were seen to originate from a central region (Pl. 2, fig. 5). The dimensions of the organisms were very variable, especially of those appearing singly or in pairs. The diameter of many of these organisms, as measured on the photomicrographs, was $0 \cdot 6-0 \cdot 7 \mu$, while the thickness of the filaments was usually more constant, averaging $0.35 \mu$. Growth of $M$. laidlawii in the presence of $50 \mu \mathrm{g} . / \mathrm{ml}$. of any of the saturated long-chain fatty acids was characterized by very few filaments; most organisms appeared either singly, in pairs or in very short chains (Pl. 1, fig. 2; Pl. 2, fig. 6). The organisms, especially those grown with palmitic or stearic acid, were bigger than those grown with the unsaturated fatty acids, many reaching a diameter of $1 \mu$.

Mycoplasma gallisepticum. This mycoplasma could not grow in tryptose broth without PPLO serum fraction, even when cholesterol was supplied to the medium. 
The organisms grown in tryptose broth supplemented with $1 \%(v / v)$ PPLO serum fraction had the typical coccobacillary form (Klienberger-Nobel, 1962). Many organisms appeared as short rods, very frequently arranged in clusters (Pl. 3, fig. 7). The organisms were usually smaller than those of $M$. laidlawii. The width of the bacillary forms averaged $0 \cdot 3 \mu$. Addition of oleic acid to the growth medium caused the appearance of some short and branched filaments (Pl. 3, fig. 8), but the phenomenon was much less pronounced than with $M$. laidlawii. Addition of 25-50 $\mu \mathrm{g}$. oleic acid $/ \mathrm{ml}$. to the tryptose broth increased the growth of $M$. gallisepticum by about $30 \%$ as measured by increase in cell protein. Palmitic acid, when added to the medium, decreased growth by $28 \%$ at a level of $50 \mu \mathrm{g} . / \mathrm{ml}$. and by $66 \%$ at a level of $100 \mu \mathrm{g} . / \mathrm{ml}$. Organisms grown in the presence of $50 \mu \mathrm{g}$. palmitic acid $/ \mathrm{ml}$. were usually spherical and bigger than those grown without the addition of fatty acids (Pl. 3, fig. 9). It is of importance to notice in this photomicrograph the growth of $M$. gallisepticum in short branched chains of cocci.

Mycoplasma sp. strain 14 (goat strain). As with $M$. gallisepticum, the goat strain required the addition of PPLO serum fraction to the tryptose medium. This strain showed a tendency to form short and branching filaments without the addition of unsaturated fatty acids to the medium (Pl. 4, fig. 10). However, filamentation was more pronounced when oleic acid was added to the medium to a final concentration of $50 \mu \mathrm{g} . / \mathrm{ml}$. Addition of palmitic acid to the growth medium in the same concentration decreased growth very markedly, the organisms appeared either singly or in pairs and their diameter was larger than that of organisms growing with oleic acid. A striking difference between organisms grown with or without the addition of oleic acid was seen after incubation of the cultures for $48 \mathrm{hr}$ at $37^{\circ}$. The culture growing in the presence of added oleic acid showed intense filamentation. The thickness of the filaments was about $0 \cdot 3-0 \cdot 4 \mu$ (Pl. 4, fig. 11). The organisms grown without the addition of oleic acid were very swollen and distorted, many appearing as empty ghosts (Pl. 4, fig. 12).

\section{DISCUSSION}

Growth of Mycoplasma laidlawii in long and branched filaments resembles very much that of the type species $M$. mycoides var. mycoides (Edward \& Freundt, 1956). The claim of Freundt $(1958,1960)$ that filament formation is a characteristic of all Mycoplasma species, including $M$. laidlawii, has been questioned by several authors (Kandler \& Kandler, 1954; Liebermeister, 1960; Dienes, 1960). Liebermeister (1960) states that branching filaments are very seldom seen in $M$. laidlawii strains, and when they are found they are artifacts of the microscopic procedure. Weibull \& Lundin (1963), using phase-contrast microscopy, could not see filaments in $\boldsymbol{M}$. laidlawii under conditions which enabled filamentation in human mycoplasma strains. Even the electron micrographs presented by Freundt (1960) to prove his point that $M$. laidlawii does produce filaments are not too convincing, because at least some of the very thin filaments (less than $0 \cdot 1 \mu$ in width) might be the result of cell destruction occurring during the drastic treatment of drying and fixation for electron microscopy. Our observations leave no doubt that $M$. laidlawii is capable of growing in long and branching filaments. The technique used, phasecontrast microscopy, does not involve any pre-treatment of the extremely plastic organisms. The photographs were taken just when the organisms and filaments settled 
on the slide. The images obtained in the photomicrographs corresponded closely to those seen moving freely in the liquid.

Formation of filaments by mycoplasma is at least in part a function of the amount of unsaturated fatty acids in the growth medium. This has been already shown for Mycoplasma mycoides var. mycoides (Rodwell \& Abbot, 1961). Cholesterol has apparently no role in filament formation in $\boldsymbol{M}$. laidlawii, because in our experiments this organism was grown in a medium with no PPLO serum fraction and the organisms contained negligible amounts of cholesterol (Razin \& Cleverdon, 1965). The dependence of filament formation on constituents of the growth medium should be kept in mind when using this property as a taxonomic criterion. The use of different media by various authors may explain the divergent views about filament formation by $M$. laidlawii.

The effects of long-chain fatty acids on morphology of Mycoplasma gallisepticum and the goat mycoplasma were less striking than with $\boldsymbol{M}$. laidlawii. This might be due to the presence of $1 \%(v / v)$ of PPLO serum fraction in the growth medium for the parasitic strains. The variety of fatty acids in this component may have masked the effects of the unsaturated fatty acids added. However, our preliminary observations indicate that basically the mode of multiplication of $\boldsymbol{M}$. gallisepticum resembles that of other mycoplasma, and short branching filaments can be formed by this organism. The goat strain, which seems to be related to $M$. mycoides var. capri (Razin, unpublished results), produces longer and more branching filaments when oleic acid is added to the growth medium. Moreover, the organisms grown with oleic acid do not show the rapid degeneration and lysis typical for the rapid decline phase of this organism grown in the presence of $1 \%$ PPLO serum fraction alone.

Inhibition of filament formation and growth by the saturated fatty acids may be caused by interference by these acids, supplied to the medium in excess, with the incorporation of the essential unsaturated fatty acids by the organisms. The need for a proper balance of fatty acids in growth media for mycoplasma and other micro-organisms has been stressed (Shorb \& Lund, 1959; Rodwell \& Abbot, 1961).

The interpretation of the present morphological observations must depend on chemical and consequently physical alterations in the mycoplasma membrane. Preliminary findings in our laboratory show that the morphological variations are accompanied by changes in osmotic fragility of the organisms indicating variations in membrane elasticity. Other observations indicate a difference in the fatty acid composition of membrane lipids of mycoplasma grown with different fatty acids. It is hoped that with the accumulation of more data an interpretation relating the morphological variations with changes in membrane composition can be postulated.

Contribution no. 123 of the Institute of Cellular Biology, University of Connecticut. One of the authors (S.R.) held a Senior Foreign Scientist Fellowship of the National Science Foundation during the work.

\section{REFERENCES}

Argaman, M. \& Razin, S. (1965). Cholesterol and cholesterol esters in Mycoplasma. J. gen. Microbiol. 38, 153.

Dienes, L. (1960). Controversial aspects of the morphology of PPLO. Ann. N.Y. Acad. Sci. 79, 356. 
Edward, D. G. FF. \& Freundt, E. A. (1956). The classification and nomenclature of organisms of the pleuropneumonia group. J. gen. Microbiol. 14, 197.

Freundt, E. A. (1958). The Mycoplasmataceae (the Pleuropneumonia Group of Organisms): Morphology, Biology and Taxonomy. Copenhagen: Munksgaard.

Freundt, E. A. (1960). Morphology and classification of the PPLO. Ann. N.Y. Acad. Sci. 79, 312.

Kandler, G. \& Kandler, O. (1954). Untersuchungen über die Morphologie und die Vermehrung der pleuropneumonieähnlichen Organismen und der L-phase der Bakterien. I. Lichtmikroskopische Untersuchungen. Arch. Mikrobiol. 21, 178.

Klifneberger-Nobed, E. (1692). Pleuropneumonia-like Organisms (PPLO), Mycoplasmataceae. London: Academic Press

Liebermeister, K. (1960). Morphology of the PPLO and $\mathrm{L}$ forms of Proteus. Ann. N.Y. Acad. Sci. 79, 326.

Lowry, O. H., Rosebrough, N. J., Farr, A. L. \& Randall, R. J. (1951). Protein measurement with the Folin phenol reagent. J. biol. Chem. 193, 265.

Polllack, J. D., Razin, S., Pollack, M. E. \& Cleverdon, R. C. (1965). Fractionation of Mycoplasma cells for enzyme localization. Life Sciences, 4, 973.

Razin, S. \& Cleverdon, R. C. (1965). Carotenoids and cholesterol in membranes of Mycoplasma laidlawii. J. gen. Microbiol. 41, 409.

Razin, S. \& Rottem, S. (1963). Fatty acid requirements of Mycoplasma laidlawii. J.gen. Microbiol. 33, 459.

Razin, S., Argaman, M. \& Avigan, J. (1963). Chemical composition of Mycoplasma cells and membranes. J. gen. Microbiol. 33, 477.

Rodwell, A. W. \& Aввот, A. (1961). The function of glycerol, cholesterol and long-chain fatty acids in the nutrition of Mycoplasma mycoides. J. gen. Microbiol. 25, 201.

Shorb, S. \& Lund, P. G. (1959). Requirements of trichomonads for unidentified growth factors, saturated and unsaturated fatty acids. J. Protozool. 6, 122.

Smith, P. F. \& Boughton, J. E. (1960). Role of protein and phospholipid in the growth of pleuropneumonia-like organisms. J. Bact. 80, 851 .

Tourtellotte, M. E., Jensen, R. G., Gander, G. W. \& Morowitz, H. J. (1963). Lipid composition and synthesis in the pleuropneumonia-like organism Mycoplasma gallisepticum. J. Bact. 86, 370.

Weibuld, C. \& Lundin, B. M. (1963). Morphology of pleuropneumonia-like organisms and bacterial L-forms grown in liquid media. J. Bact. 85, 440.

\section{EXPLANATION OF PLATES}

Plate 1

Mycoplasma laidlawii

Fig. 1. Organisms grown for $24 \mathrm{hr}$ at $37^{\circ}$ in tryptose broth with no fatty acid added. $\times 2700$.

Fig. 2. Organisms grown for $24 \mathrm{hr}$ at $37^{\circ}$ in tryptose broth supplemented with $50 \mu \mathrm{g}$. palmitic acid./ml. $\times 2700$.

Fig. 3. Organisms grown for $24 \mathrm{hr}$ at $37^{\circ}$ in tryptose broth supplemented with $50 \mu \mathrm{g}$. oleic acid./ml. $\times 2700$.

Plate 2

\section{Mycoplasma laidlawii}

Fig. 4. A microcolony formed after $24 \mathrm{hr}$ incubation at $37^{\circ}$ in tryptose broth supplemented with $50 \mu \mathrm{g}$. oleic acid. $/ \mathrm{ml} . \times 1250$.

Fig. 5. A microcolony formed after $24 \mathrm{hr}$ incubation at $37^{\circ}$ in tryptose broth supplemented with $50 \mu$ g. linolenic acid. $/ \mathrm{ml} . \times 1250$.

Fig. 6. Organisms grown for $24 \mathrm{hr}$ at $37^{\circ}$ in tryptose broth supplemented with $50 \mu \mathrm{g}$. stearic acid. $/ \mathrm{ml} . \times 2700$. 


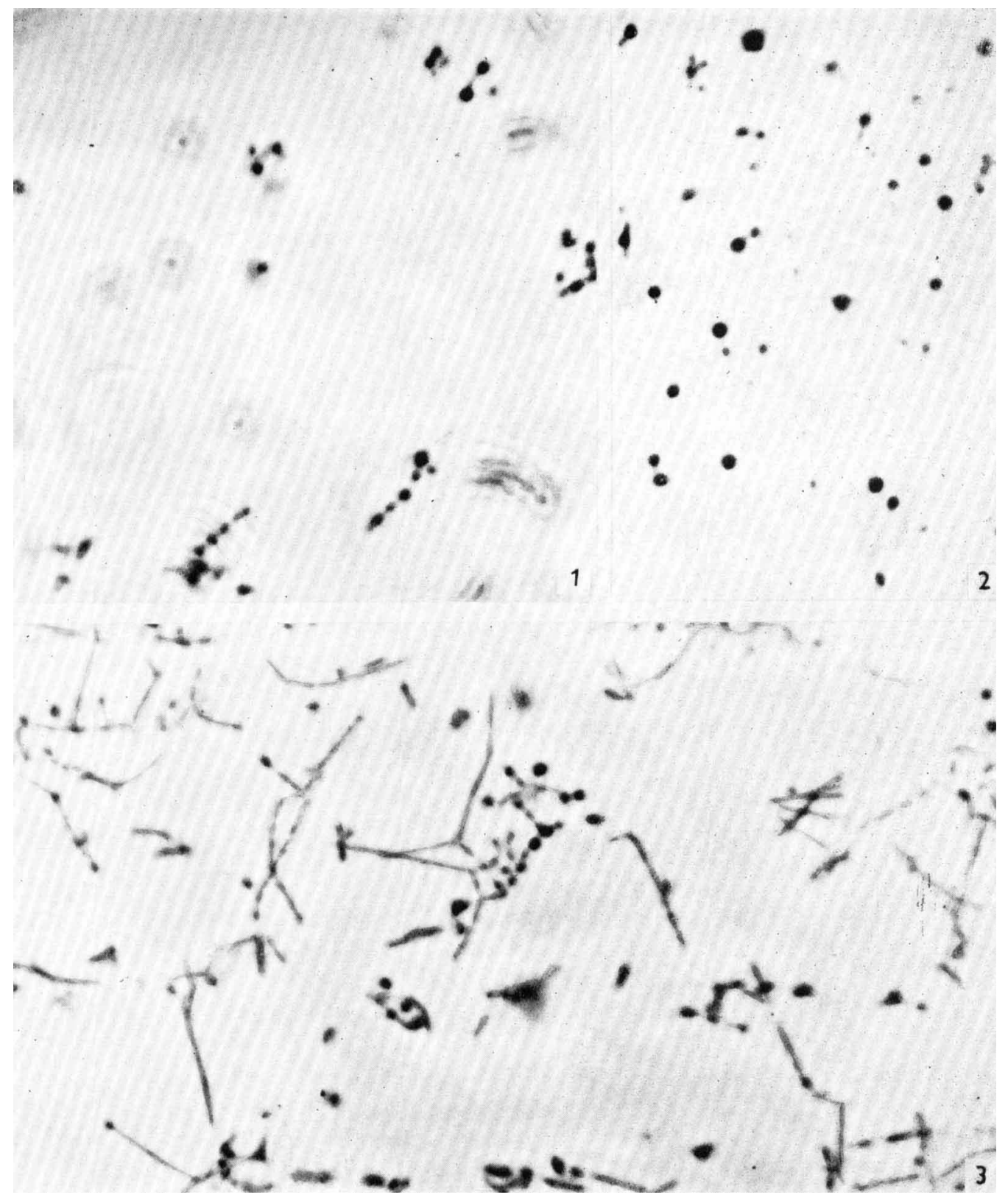


Journal of General Microbiology, Vol. 42, No. 1
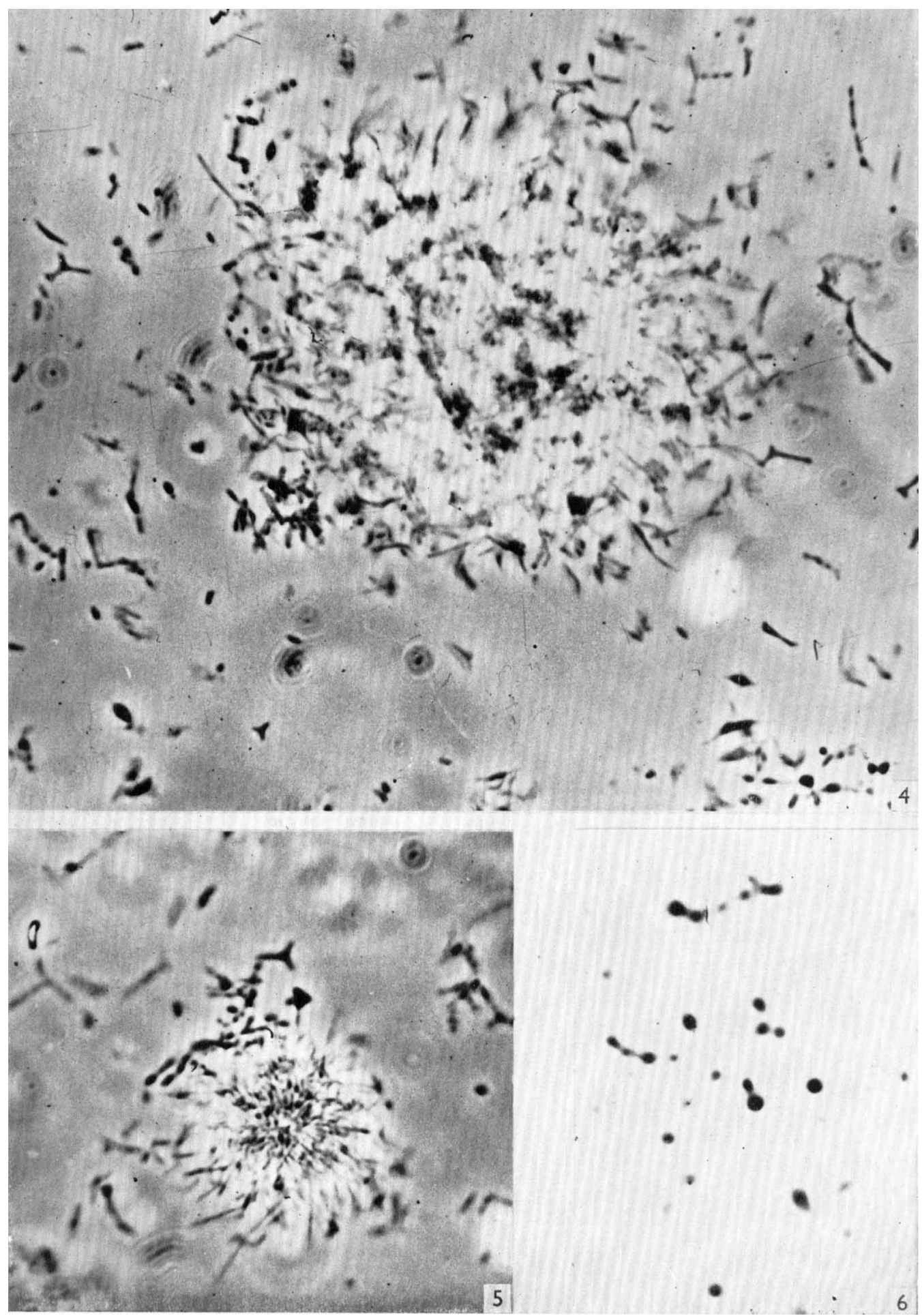

S. RAZIN, B. J. COSENZA AND M. E. TOURTELLOTTE 
Journal of General Microbiology, Vol. 42, No. 1

Plate 3

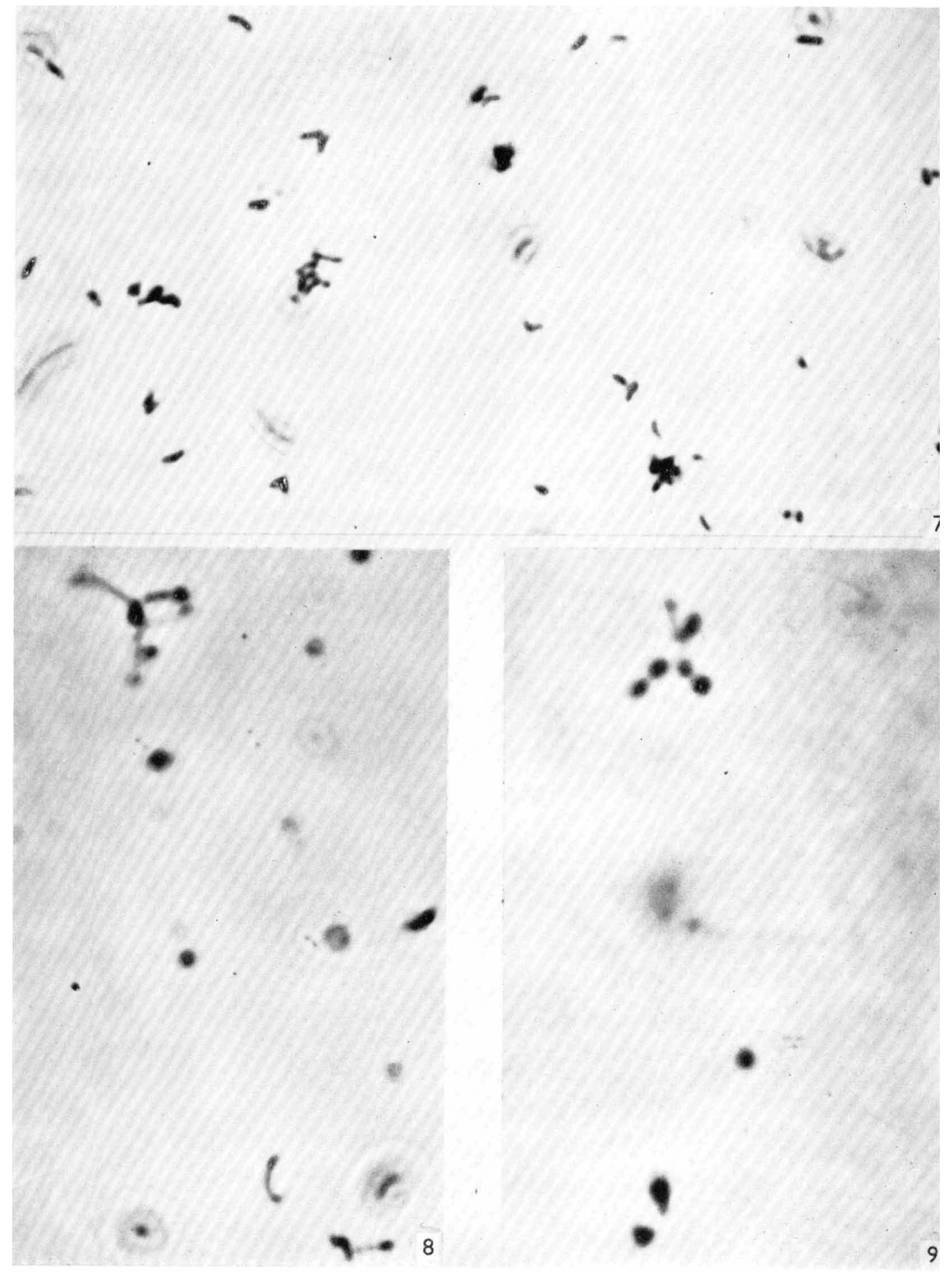

S. RAZIN, B. J. COSENZA AND M. E. TOURTELI.OTTE 


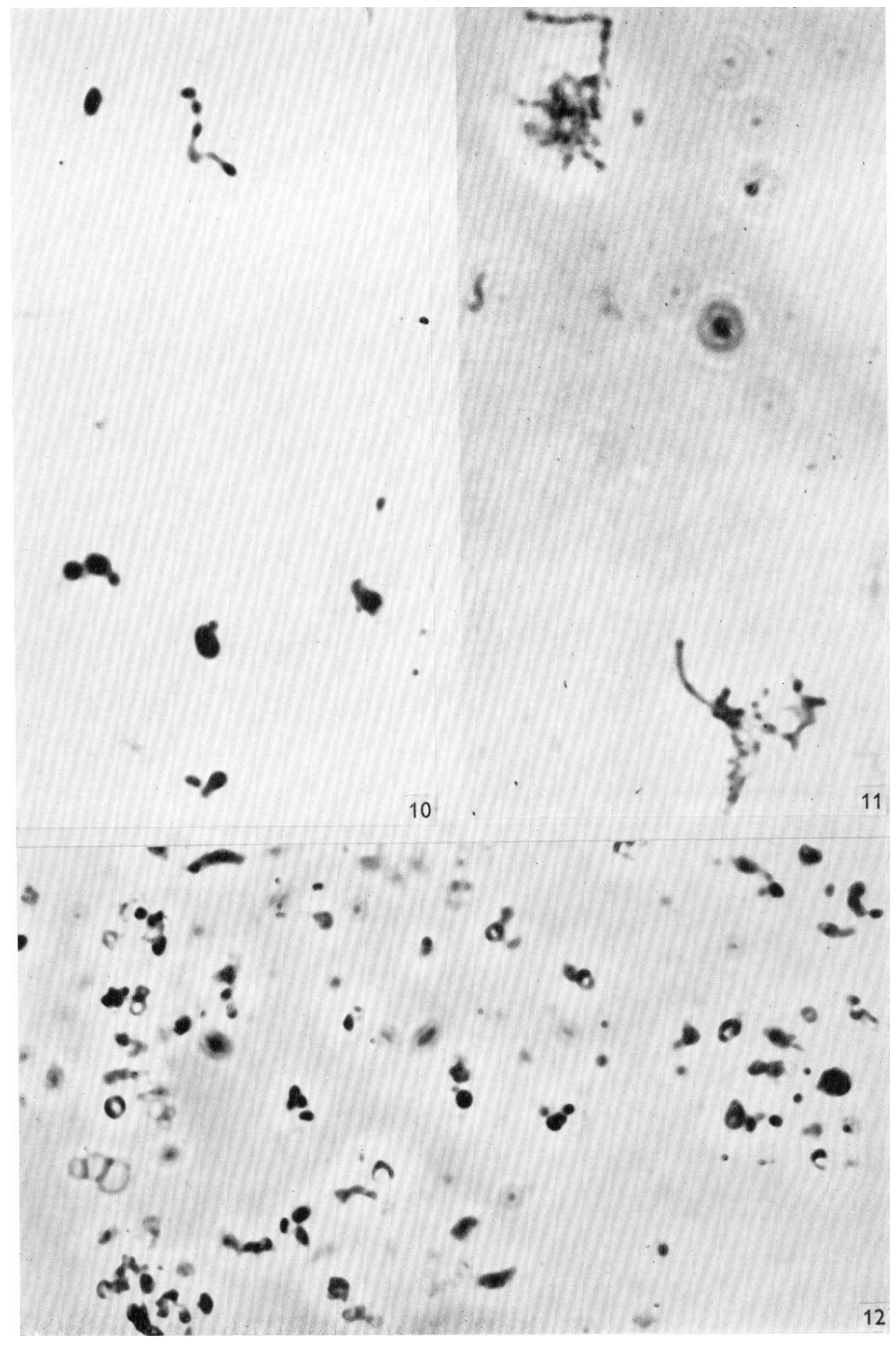

S. RAZIN, B. J. COSENZA AND M. E. TOURTELLOTTE 


\section{Plate 3}

\section{Mycoplasma gallisepticum}

Fig. 7. Organisms grown for $24 \mathrm{hr}$ at $37^{\circ}$ in tryptose broth containing $1 \%$ (v/v) PPLO serum fraction. $\times 2700$.

Fig. 8. Organisms grown for $24 \mathrm{hr}$ at $37^{\circ}$ in tryptose broth supplemented with $1 \%$ (v/v) PPLO serum fraction and $50 \mu \mathrm{g}$. oleic acid. $/ \mathrm{ml} . \times 2700$.

Fig. 9. Organisms grown for $24 \mathrm{hr}$ at $37^{\circ}$ in tryptose broth supplemented with $1 \%$ (v/v) PPLO serum fraction and $50 \mu \mathrm{g}$. palmitic acid. $/ \mathrm{ml} . \times 3850$.

\section{Prate 4}

\section{Mycoplasma sp. strain 14 (goat strain)}

Fig. 10. Organisms grown for $24 \mathrm{hr}$ at $87^{\circ}$ in tryptose broth supplemented with $1 \%$ PPLO serum fraction. $\times 2700$.

Fig. 11. Organisms grown for $48 \mathrm{hr}$ at $37^{\circ}$ in tryptose broth supplemented with $1 \%$ (v/v) PPLO serum fraction and $50 \mu \mathrm{g}$. oleic acid. $/ \mathrm{ml} . \times 2700$.

Fig. 12. Organisms grown for $48 \mathrm{hr}$ at $37^{\circ}$ in tryptose broth supplemented with $1 \%$ (v/v) PPLO serum fraction only. $\times 1250$. 